CHALHOUB, Sidney. Machado de Assis Historiador. São Paulo: Companhia das Letras, 2003.

\title{
Machado de Assis Historiador
}

Natália de Santanna Guerellus ${ }^{1}$

As alusões históricas presentes na obra de Machado de Assis já vem sendo estudadas há pelo menos vinte anos por autores como John Gledson e Roberto Shwarz. Baseado nestes autores e aliado ao material mais recente acerca da historiografia sobre a escravidão no Brasil, Sidney Chalhoub propõe uma nova interpretação de Machado de Assis e do período em que o paternalismo atingiu o ápice da crise.

Apesar de ser conhecido como historiador da escravidão e da vida operária do Rio de Janeiro de fins do século XIX, Chalhoub aventurou-se pela crítica literária, utilizando-se da obra machadiana para elucidar o processo da emancipação dos escravos em fins do Império. No entanto, sua pesquisa não parou por aí, passando a utilizar-se das idéias políticas e sociais do romancista para complementar o retrato social e crítico do país.

De fato, alem de contos e romances, Joaquim Maria Machado de Assis assinou uma quantidade considerável de pareceres e relatórios ministeriais, durante a ocupação do cargo de chefe da segunda seção da Secretaria de Estado dos Negócios d’Agricultura. Sua opinião acerca da escravidão, assunto indispensável nas discussões ministeriais da época, foi descrita por Chalhoub especialmente na segunda parte do livro e de modo a compará-la com demais políticos influentes no Conselho do Estado.

Num primeiro momento, a crítica feita por Chalhoub a alguns romances machadianos, procurou apoiar-se nas críticas já realizadas por Gledson e Shwarz, mas questionando também estes autores. E foi assim que a interpretação de obras como Helena, Memórias Póstumas e Iaiá Garcia conduziram o historiador à identificação de três classes, ou duas de forma simplificada: os senhores e os dependentes e escravos.

Através dessa divisão, Chalhoub conseguiu elucidar sua opinião sobre a forma machadiana de descrever a ideologia senhorial, a vontade inviolável e o nariz metafísico que habitava cada fronte de um proprietário no Brasil do século XIX. O leitor de Chalhoub é convencido da prepotência que permeava a imagem do dono de escravos, ao redor do qual o mundo construía-se, servia para servi-lo, moldava-se a seu bel prazer.

No entanto, uma questão proposta nos três primeiros capítulos e que é retomada na segunda parte da pesquisa, trata da posição de estudos recentes sobre a escravidão que apontam para a relação entre senhores e dependentes, havendo subordinação, mas não necessariamente passividade. "O exercício favorito da historiografia anterior à renovação do tema da escravidão era comparar a situação no Brasil do século XIX com a Europa no mesmo período, para concluir que lá, sim, havia movimento operário, consciência de classe e todo o resto. Aqui só "ausência", escravo-coisa e baboseiras do gênero, em geral, defendidas com muita fantasia teórica e profunda ignorância do que há nos arquivos brasileiros sobre a experiência dos escravos na escravidão. Faziam assim tábua rasa da luta dos trabalhadores escravos pela liberdade, talvez o aspecto mais determinante da história brasileira do Oitocentos”, argumenta Chalhoub ementrevista ${ }^{2}$.

Assim, a escravidão não seria defendida explicitamente por Machado, mas subentendida na obra machadiana, sempre em relação ao lócus do dependente. Exemplo disso encontra-se nas vinculações entre personagem como Estácio e Helena, Brás e D. Plácida, D. Glória e José Dias, nos quais o medo maior do dependente é a extrema subordinação, ou seja, a escravidão.

É nesse sentido que a dependência também imprime nos sujeitos, diferentes formas de atuar para obter benefícios de seus senhores, sempre envolvendo-os em sua própria fantasia dos narizes metafísicos, segundo a interpretação de Chalhoub.

Não limitando-se à estrutura, o pesquisador demonstrou que as mudanças históricas também tiveram efeito sobre a obra de Machado, havendo contraste nítido entre o período Regencial, considerado turbulento, e o Segundo Reinado, principalmente a década de 1850, auge da ideologia senhorial.

No entanto, a análise mais interessante, e também cansativa, de Chalhoub, deu-se na segunda e maior parte do livro, em que o historiador fez um apanhado dos documentos que encontrou no Arquivo Nacional e que tratavam dos tramites legais, livros de minutas, ofícios e relatórios ministeriais que envolviam a assinatura ou a participação do funcionário público Machado de Assis e que pertenciam ao período de aplicação da lei de 28 de setembro de 1871.

A década de 1870 viu crescer a crise institucional da escravidão que havia começado "com a adoção dos princípios de humanidade proclamada desde meados do século XVIII”." A prestigiosa sociedade abolicionista francesa, a Comité pour l'Abolition de l'Esclavage, em carta enviada no ano de 1866, pressionou D. Pedro II a promover, o mais rápido possível, as discussões acerca da abolição.

\footnotetext{
${ }^{1}$ Graduanda em História na Universidade Federal do Paraná (PET - História).

${ }^{2}$ http://www.historiadoreletronico.com.br/secoes/cade/108.html

${ }^{3}$ BOMFIM, Manoel. O Brasil nação. Realidade e Soberania Brasileira. Rio de Janeiro: Topbooks, 1986. Pág 372.
} 
Problema este encarado pelo Conselho de Estado com a mais freqüente "arte de bordejar" dos conselheiros brasileiros do período. "O resultado dessa tensão entre conveniência política e convicções escravocratas foi a formulação, por parte da maioria dos conselheiros, de argumentos sibilinos destinados a concordar com o imperador em que a emancipação era questão decidida, ao mesmo tempo que sustentava a opinião de que nada devia ser feito sobre o assunto"4.

Nesse turbulento mar da abolição, e especificamente no ano de 1871, um gabinete havia acabado de subir ao poder, chefiado pelo visconde de São Vicente, autor de estudos iniciais e redator de projetos de leis de emancipação gradual norteados pela idéia do ventre livre. Em 28 de setembro do mesmo ano foi proclamada a lei que libertava o ventre das escravas.

Além das intermináveis discussões políticas descritas por Chalhoub acerca do nome que seria dado ao beneficiado da lei (se 'liberto’, se ‘ingênuo', se ‘filho livre de mulher escrava'), a aplicação da norma era questão constante nos anos posteriores, e é neste interim que figura o funcionário público Machado de Assis.

Nesse sentido, Chalhoub faz uma longa descrição dos pronunciamentos de alguns conselheiros como o visconde de Olinda, José Maria da Silva Paranhos, Perdigão Malheiro entre vários outros, para tentar esclarecer a importância que se dava ao tema da abolição no Conselho do Estado, e também a fim de recuperar a discussão iniciada na primeira parte do livro, relativa à crise da ideologia senhorial.

O ‘bordejo' dos conselheiros deu-se num momento em que o Brasil imperial oferecia ao mundo o curioso espetáculo de um país no qual todos condenavam a escravidão, mas quase ninguém queria dar um passo para viver sem ela. A aplicação, pois, da lei do Ventre Livre, foi carregada da mesma mudança constante que permeou o projeto da lei, ou seja, o texto confuso e muitas vezes ambíguo tornava a aplicação da norma uma fornecedora constantes de tramites legais entre o liberta não liberta dos escravos da época. E cabia à segunda seção da Diretoria da Agricultura do Ministério da Agricultura dar conta da efetuação .

Esse contato entre o literato e o cidadão Machado de Assis provocou mudanças nas obras posteriores, principalmente a partir de Memórias Póstumas, onde a ideologia senhorial manipula todas as teias sociais em redor, no ápice do egocentrismo representado por Brás Cubas.

É esta mesma ideologia que entra em crise no final do Império e vê-se ameaçada pela emancipação servil, pela necessidade da ‘civilização’ e pelo triste espetáculo de ver o Brasil representar o último baluarte da escravidão.

Conclui-se então a tese principal defendida por Chalhoub, de que as mudanças históricas da década de 1870 influenciaram a obra literária de Machado.

Além de uma análise literária em um primeiro momento e legislativa política num segundo momento, o pesquisador procurou, para efetivar sua tese, a análise de outros literatos, como Joaquim Manoel de Macedo e José de Alencar, que ajudaram na compreensão de todo o imaginário da escravidão no final do Império e também da lógica de Joaquim Maria Machado de Assis impressa na Memórias e na História.

${ }^{4}$ CHALHOUB, Sidney. Machado de Assis Historiador. São Paulo: Companhia das Letras, 2003. Pág. 140. 